\title{
Fernando Soto Aparicio, un hombre llamado Latinoamérica*
}

Fernando Soto Aparicio (Socha, Boyacá, 11 de octubre de 1933-Bogotá, 2 de mayo de 2016)"

Carlos Soto Mancipe

María Teresa Escobar López

Jorge Pinzón

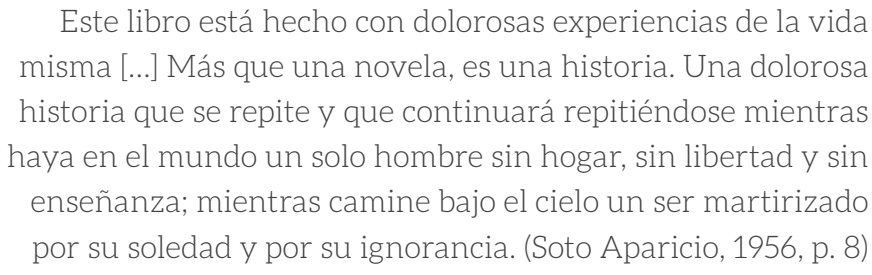

Miré su pecho que arrítmico se movía cansado de tanta lucha. Vi a mi madre que en silencio seguía orando, como todo ese fin de semana. Me acerqué a mi esposa para tener fortaleza. Volví a mi padre y puse mi mano sobre su frente, respiró lento y paró, volvió a respirar y paró definitivamente. Mis manos no se despegaron de su frente, cerré sus ojos, sabía que su lucha apenas terminaba, descansó. Mi madre se paró junto a la cama, rezó un poco más duro, le dio un beso y con una tranquilidad abrumadora, con el amor más grande del mundo, lo despidió. Eran las 8:40 a. m. del 2 de mayo de 2016.

Después de un año de lucha, con dolores profundos y terribles que lo impulsaron a escribir su Bitácora del agonizante, su vieja máquina Olivetti guarda silencio, no se escucha más el repiqueteo sobre el papel cuando trabajaba con la palabra que escribía a más de 100 por minuto con los dedos del corazón. No se llenarán más páginas en blanco con sus historias y como siempre dijo: "cuando mi voz se calle, mis libros gritarán por mi"; esa labor apenas empieza.

En el artículo "Un mar de silencios en un mundo de palabras" mi hermano Jaime lo describe y recuerda de una forma particular:

Recuerdo que era un completo desastre para las labores manuales. Los pequeños arreglos caseros (lo que fuera más allá de cambiar un bombillo) se volvían complejos enredos de cables, herramientas, machucones y sufrimientos. Mi mamá tenía que acudir en su ayuda y casi siempre terminaban

\footnotetext{
* Con este título, y parte de contenido, se publica como introducción en la obra póstuma del maestro Soto Aparicio Ellas y yo (2017).

** Este escrito a "tres manos" cuenta con la participación de Carlos Soto, hijo del maestro Soto Aparicio -pintor y diseñador gráfico, decano de Diseño Gráfico de la Corporación Universitaria Unitec, Bogotá-; María Teresa Escobar y Jorge Pinzón, todos participantes de la investigación 2356 Bioética narrativa en la literatura de Fernando Soto Aparicio. problemática moral y aportes para la resolución de conflictos y toma de decisiones. INV-HUM 2352.
} 
llamando al plomero o al electricista o al que fuera, quien amén de realizar el trabajo debía "deshacer los entuertos" que mi papá había ocasionado. Si por él fuera, los carros no debieran tener llantas para no tener que cambiarlas, y lo único que hacía bien era ponerle gasolina pues de todas las demás cosas de mantenimiento se olvidaba. Sí, mi papá era negado para las cosas cotidianas. Pero era un superhéroe a la hora de escuchar y dar consejos.

Nos dejó una gran lección que dice que el amor es el eje de la vida, su hilo conductor, el motivo y la razón:

Pienso que el amor, como la vida, es un espejo y que nos devuelve la cara con que lo miramos; y que el amor que es entrega, que es darse por completo, implica también recibir al otro en la misma medida y es un sendero de doble vía que no termina nunca y que siempre, por fortuna, va acompañando este camino de la vida, van los dos paralelos; camino y sendero, buscando siempre ese momento pleno que es lo que tal vez nos justifica, lo que nos da un norte, lo que se convierte en una brújula para guiarnos en esta senda a veces difícil de la vida. El amor es, pues, el compañero por excelencia, lo que no traiciona nunca y es lo que nos proyecta más allá del término fijado para la vida.

Toda su obra tiene un norte, una preocupación constante por denunciar, mostrar y evidenciar las angustias y las preguntas del hombre de este continente:

El eje central de todos mis libros es el hombre de América Latina, con su problemática, con su angustia cotidiana, con su lucha por sobrevivir, con su rebeldía contra la injusticia, con su cólera contra los opresores; es el hombre que tiene que vender su fuerza de trabajo al mejor postor; el que no tiene una casa dónde vivir; el que, en este mundo ancho y ajeno, no tuvo un surco propio; el que aprende a beber con la leche materna la rebeldía contra una situación social insostenible; el que, de pronto en medio de toda esa barbarie cotidiana, sigue buscando la paz; el que no tiene para comprar un cuaderno para sus hijos; el que ve que el Estado ha ido cerrando las escuelas y condenando al pueblo al analfabetismo; el que mira aterrado cómo ese mismo Estado, ese mismo Gobierno ha ido cerrando los hospitales, hasta el punto en que ya la gente pobre no tiene ningún servicio social en el terreno de la salud; el que contempla con asombro cómo el Gobierno que él eligió para que lo llevara por el buen camino de la paz, de la concordia, de la convivencia, gasta todo el dinero del presupuesto nacional en pólvora [...] estamos quemando el poco dinero que tenemos en la guerra y no gastamos un solo centavo para la paz.

Un hombre que guardaba su cotidianidad para escribir y leer, tranquilo y sereno. Entre los muchos recuerdos, mi hermano Jaime termina su reflexión y anota sobre mi padre:

Tuve, con mis hermanos, la felicidad y la bendición de tener y disfrutar a mi papá durante 60 años, muchos años más que los que la mayoría de las personas en este país tienen a sus padres vivos. Hoy, con mis cuatro hermanos de carne y hueso y con mis 72 hermanos de papel y tinta sentimos la soledad y su ausencia. La vida nos dio la oportunidad de devolverle una partecita de todo lo que nos brindó. Al cuidarlo durante su enfermedad, se invirtieron los papeles y él pasó a ser como nuestro hijo. Así lo sentimos: frágil, indefenso, asustado, triste, dolorido, desesperanzado... Ahí estábamos 
todos: sus cinco hijos bajo la batuta organizada, diligente, amorosa y devota de mi mamá y apoyados de manera incondicional por mi cuñada María Consuelo, su hermano Eduardo y su cuñado Alfonso, dedicados a hacerle menos penosos sus últimos días, a consentirlo, a mimarlo, a reconfortarlo, a escondérselo por unos días más a la muerte. Él dispuso que en su habitación pusiéramos muchos libros, eran pilas de libros que lo acompañaban en sus sueños tormentosos y en sus desvelos. Quiso también que la luz estuviera permanentemente encendida, pensábamos nosotros que porque tenía miedo de que la parca aprovechara alevemente la oscuridad, pero creo yo que era para ver a sus libros haciéndole compañía, montando guardia, protegiéndolo y abrigándolo, prestos a entregarse a Caronte para pagar su viaje más allá de la laguna Estigia, surcando el Aqueronte hacia la eternidad y la gloria.

Por eso, junto a su obra monumental, leída por miles, sus versos que enamoran, sus palabras que denuncian las injusticias, su fe en el amor, la lucha sostenida de forma rabiosa durante un año contra su enfermedad, sabiendo que ya le había ganado la carrera a la muerte del olvido a través de sus libros que gritarían por él eternamente, la imagen que guardamos como escritor y como hombre perdurará por siempre junto a millones de lectores que seguirán recorriendo sus páginas para ser de su obra un maravilloso legado a las letras castellanas en esta parte de América para el mundo.

Carlos Soto

Maestro, usted sigue aquí.

A un año de su partida, su caminar pausado, su dulce sonrisa, sus comentarios inteligentes, oportunos, a veces mordaces, la mayoría amables siguen estando aquí. Su presencia se siente en la Facultad de Educación y Humanidades. Está en el recuerdo grato de su sabiduría, sus amables gestos, en la evocación de su paciencia infinita e inteligente frente a la torpeza y la mediocridad, en la cita oportuna que se escucha frecuentemente de sus frases ilustradas y celebres pronunciadas por parte de algún profesor; en las reuniones del club de lectura que lleva su nombre y que usted fundó e impulso hasta último momento, en las investigaciones que hacemos de sus obras de profundo contenido histórico, político, bioético, ${ }^{1}$ en el estudio de sus libros y poemas en el interior de las clases de lectoescritura; realmente, usted sigue aquí.

Puede suceder que no resulte necesario tener que interactuar de manera personal con un escritor para poder conocerlo en su dimensión más profunda que es la de su actuar personal, ahí en el día a día, en la cotidianidad que desnuda, en el simple mundo de la letra menuda.

$1 \mathrm{Al}$ respecto, en 2017 hemos estado realizando la investigación Bioética narrativa en la literatura de Fernando Soto Aparicio. Problemática moral y aportes para la resolución de conflictos y toma de decisiones. INV-HUM 2352 Investigadora principal: María Teresa Escobar López; coinvestigador: Luis Flores Portero, docente investigador de la Universidad Militar Nueva Granada. 
Me sucedió con Cortázar, después con Serrat y casi al mismo tiempo con Blades. Solo leyéndolos y escuchándolos, los supe profundamente humanos.

Con el maestro Fernando Soto Aparicio no ha sido diferente. Nunca pude mirar de cerca sus ojos, ni experimentar la sensación de estar al frente de un gran ser humano. Solo supe que me perdía el deleite de su conversación directa y que sus prosas y estos poemas recientes de siempre daban fe de su grandeza en lo personal. (Jorge Pinzón)

$\&$

Desde nuestros puestos de trabajo ya no se observan sus permanentes compañeros de cubículo: sus libros y sus gatos. ¿Quién no sabía de su devoción por la lectura y el afán con que esperaba que las personas leyeran y entendieran que eso nos hace mejores personas? Frecuentes visitantes llegaban a la oficina queriendo abrazarlo, felicitarlo por su trabajo literario, recibir un consejo para escribir, una luz, un tip, alguna ilustración sobre la forma como usted realizaba su labor poética y literaria; otros allanaban su escritorio para hacerle un registro fílmico o tomarse una fotografía. Casi siempre los veíamos salir no solo con el recuerdo grato de ser atendidos con la sencillez que solo posee quien es sabio, sino que también solían llevar bajo el brazo un ejemplar de sus libros siempre regalados con absoluto desprendimiento y complacencia, aduciendo sus célebres argumentos: "un libro debe andar, no hay nada más triste que un libro guardado o exhibido en un escaparate", o "un libro no tiene cien hojas, un libro tiene cien alas, un libro nos lleva a mundos desconocidos, nos asoma por ventanas maravillosas, nos hace volar la imaginación, nos mueve sentimientos y sensaciones que de otra manera no se podría".

$\&$

Hace ya tiempo, yo frecuentaba un viejo café situado en el centro de la ciudad, allí sentado en una silla roja tan vieja como la mesa y como el café mismo, solía tomar un tinto delicioso que salía por las arterias de una inmensa máquina alemana traída en 1938 y manipulada únicamente por la señora Inés, la administradora del lugar.

En alguna ocasión, sentado al fondo del salón estaba el maestro Soto Aparicio, degustando el tinto y leyendo-escribiendo lo que tal vez fuera la corrección de una de sus numerosas obras.

Las personas lo saludaban muy respetuosamente y algunos le preguntaban por sus cosas, sus escritos. Él los saludaba y les contestaba de manera amplia, como queriendo retener cada instante de conversación, cada pedazo de existencia del otro, siendo generoso con la palabra.

Quise entonces acercarme a saludarlo, como los otros lo hacían, pero no lo hice, no sabía qué decirle. Solo mirarlo a prudente distancia. 
Al fondo se escuchaba, a un volumen moderado, el bambuco Cuatro preguntas interpretado por Obdulio y Julián.

\section{$\&$}

La colección de gatos que adornaban la oficina constituían testimonio de amor y admiración por ellos y a la vez demostración del amor expresado por quienes lo conocían y sabían que esto hacia más amable su permanencia en la oficina. Ellos fueron testigos de excepción del tiempo que tuvimos el privilegio de contar con su presencia en esta casa de estudios por más de 17 años.

En una entrevista realizada por Hernán Orjuela para televisión, a propósito de la publicación de Camino que anda, el maestro, en su estilo sin igual, narra la forma como este texto da cuenta de la historia reciente de América Latina, relatando el rigor que representa la investigación que antecede no solo a esta, sino también a cada una de sus obras, más de setenta libros, detrás de los cuales existe un estudio concienzudo y estricto. Los cuadernos secretos, en los que registraba toda la labor que antecedía a sus libros, son el testimonio cierto del escritor social y comprometido que da cuenta de la historia de nuestro tiempo, labor cuya cotidianeidad tuvimos la fortuna de acompañar en los últimos años, su afán por registrar y acudir a los amigos y familiares cercanos para rastrear por ejemplo las culturas indígenas del sur del continente para tener más información de la que ya poseía y escribir La sed del agua. Cómo no recordar y extrañar también los hermosos escritos que nos hacía llegar el día de la mujer, el día de la madre o saludo de fin de año; siempre llenos de poesía y sabiduría.

\section{$\&$}

Descubrí su poesía bastante tempo después de saber de algunas de sus novelas, novelas que me "pusieron" a leer en el colegio y otras pocas que leí por gusto propio cuando las preguntas sobre la sociedad y la vida de las gentes me comenzaban a rondar la cabeza y el sentir. Entonces tuve certeza de la preocupación del maestro Soto Aparicio por los sin nombre, los desventurados, los excluidos, las gentes por las que yo me preguntaba y me fue revelada su permanente denuncia de lo acontecido en sus narraciones que me parecían denuncias reales.

El maestro debió haber hecho parte de ese selecto grupo de escritores latinoamericanos ampliamente reconocidos que narraban lo que sucedía en el continente en los duros tiempos de las dictaduras y las rebeldías. Pero él no tuvo tamaño reconocimiento. (Jorge Pinzón)

\section{$\&$}

Tan duros (esos "tiempos de las dictaduras y las rebeldías") como se refleja en las vidas de sus incontables personajes. En su primera novela, Los bienaventurados, los personajes son castigados sin 
aparente razón o culpa, como es el caso de Mario, quien poco a poco va pagando un alto precio por haber dado rienda suelta a sus impulsos amorosos hacia Tona: "El joven cayó al piso, bañado en sangre. Era parte de su castigo" (p. 55). ${ }^{2}$ En cierto modo, los personajes experimentan esa misma falta de reconocimiento o comprensión por un entorno marcadamente hostil, todo lo cual hace que su autor los llame, no sin la necesaria ironía, "bienaventurados. (Luis Flores Portero)

¿Cómo no recordar la poesía de Fernando Soto Aparicio? Esta, con la que privilegiadamente nos alegraba las horas de trabajo, ocupa un lugar de honor en la poesía colombiana y latinoamericana; devela no solamente su riqueza literaria y artística, sino además sus valores, su sentir, su basta sapiencia. El maestro lograba, y lo seguirá haciendo con su fructífera obra como repetía constantemente, ser la expresión de una sociedad muda: "el escritor tiene la obligación de hablar por ellos, por los que se callan, por los que no tienen voz, por los que tienen miedo". Su afán por educar a través de la literatura era evidente, sus lemas acerca de la lectura eran su diario quehacer y vivir; sabía como nadie que quien leyera y apreciara las artes se alejaría de la ignorancia y la violencia. Fue pregonero de la paz y el amor como ninguno. ${ }^{3}$

Fernando Soto Aparicio fue y seguirá siendo el escritor social y humano que supo plasmar como pocos la historia de su tiempo, crítico siempre frente a la corrupción, la violencia y cualquier forma de injusticia; fiel a sus principios y valores, lograba personificar la verdadera esencia de una vida ética. El maestro Soto Aparicio, sin duda, pertenece a la categoría de humanista a carta cabal. Poseía la generosidad que le fue tan esquiva a sus compañeros en las artes y tan ausente en el Estado.

La literatura es una disciplina draconiana, terrible, pero maravillosa. Hay gente muy valiosa, no diré nombres porque se me escaparía alguno, pero hay gente que ha recogido las banderas que tal vez nosotros vamos a dejar. Hay gente que nos reemplazará con lujo, que nos está ganando, que ha aceptado el reto internacional de la literatura. Yo estoy muy complacido por eso, cada nuevo autor es como si yo lo hubiera descubierto, es una gran alegría. ${ }^{4}$

$\&$

Descubrí su poesía bastante tempo después, cuando queriendo hacerles caso a varios amigos que sabían de sus virtudes poéticas me encontré con las letras del amor y la exaltación de la mujer, y supe que era cierto:

2 Soto Aparicio, F. (2010). Los bienaventurados. Bogotá: Universidad Militar Nueva Granada.

3 Baste recordar que se anticipó a proclamar la cátedra de la paz y la necesidad de enseñar y cultivar el amor. En textos como Recomendación para todos los días en Cartilla para mejorar el mundo:_"Debería existir una cátedra que se llamara, quizás, "Pedagogía de la paz"; donde se enseñara a sembrar un árbol, a construir un tablero, a escribir una idea. Y otra clase que no fuera simplemente Educación sexual, sino "Preparación para el Amor". Tal vez así enderezaríamos el torcido caminado del mundo, para que fuera realmente mejor." Revista Investigación y Desarrollo Social 1999.

4 Entrevista con Juan Villamil. "Siempre he estado de pelea con Dios": Fernando Soto Aparicio 24 de abril de 2012. 
Cuerpo maduro y dúctil para el goce.

Cuerpo de duna, viento de palmera,

oquedad de bahía iluminada.

(del poema Cuerpo maduro y dúctil).

O del poema Pecado:

Tu piel ya no me sabe a los pecados

a que quizá pudo saberme un día.

Tus ojos me contemplan fatigados

porque se les murió la fantasía.

O sencillamente de la vida y su desenlace en el poema Olvido

Oye: cuando me vaya de la vida

me sentirás tan cerca como ahora.

En el canto de un pájaro en el alba,

en la bruma que surja entre las rosas,

en los hondos espejos del aljibe

donde las nubes tímidas se ahogan.

en el canto de un niño por la calle,

en el acre sabor de la derrota,

bailando en la alegría de la siembra

con los brazos abiertos a la aurora

para que en ellos se detenga el viento

y hagan su nuevo nido las palomas.

$\&$

Muy pocos en el interior del país hacen justicia a su extensa y valiosa obra. Sorprende oír cómo escritores que pertenecen a la sociedad del mutuo elogio se ponderan entre ellos sin siquiera mencionar al maestro Soto Aparicio, que a todas luces es uno de los grandes. Al Estado mismo para el cual trabajó más de veinte años en el tribunal de Santa Rosa de Viterbo y en el Consulado de Francia, y del cual no recibió nada en retribución, ni siquiera los derechos que por ley tenia de una pensión de vejez. En la entrevista antes mencionada con Hernán Orjuela, este periodista refería que era increíble que en Colombia no hubiese recibido premio alguno por parte del Gobierno, mientras que por cuenta de instituciones nacionales, de otros países y continentes, los títulos y condecoraciones representan una larga lista.

Al maestro Soto Aparicio le ocurrió igual que a uno de los personajes históricos de sus libros, "Pedro Pascasio, héroe antes de los 12 años", a quien la recompensa prometida nunca le llegó. La justicia, a Pedro Pascasio, se la hace el texto del maestro, mostrando su entereza y rectitud. Él 
registra en ese libro cómo la historia de la independencia pudiese haber seguido otro rumbo de no ser por este intrépido y olvidado adolescente.

La verdad es que Fernando Soto Aparicio fue un escritor al que le tocó forjarse un nombre contra la marea, como suele suceder con quien no tiene precio ni le hace juego al poder o al dinero. Por el contrario, como don Quijote, se ocupaba de la injusticia y los menesterosos. Él mismo refería cómo, tras tocar muchas puertas de universidades, editoriales, etc. en nuestro país, fue en España, participando en un concurso, donde logró publicar su primer libro: Los bienaventurados. Realmente, su papel en el mundo obedecía un tanto a lo dicho por Gonzalo Arango en 1966:

\footnotetext{
Este Fernando Aparicio, tan sereno, tan quieto, tan ausente en su presencia, me dio la impresión de ser como esos postes callejeros que no se ven, que no se notan porque siempre están allí, netos y necesarios, y que para descubrirlos hay que tropezar con ellos, y hasta reventarse las narices contra la solidez de su resistencia. Así lo vi y lo sentí como un poste de electricidad cuya existencia nos descubre un perro cuando hace pipí, pero tan presente a pesar de las miradas que pasan indiferentes. Tan necesario y justificado en su condición de 'poste' porque sabe que su misión es estar ahí para transmitir la luz, para comunicar a los hombres.
}

$\&$

Hoy día, por muy bonitas razones, me encuentro más cerca del maestro Soto Aparicio, paradójicamente después de su partida. Hoy estoy seguro de que me acercaría a su mesa y, sin saber exactamente qué preguntarle, tal vez intentaría conversar acerca de las músicas, del pasillo y su atávico ancestro culposo, pero bello.

$\varepsilon$

Es seguro que el tiempo y la importancia indudable de su obra lo inmortalizarán en la historia colombiana, latinoamericana y mundial. Por ahora solo basta decir que cada vez se siente más su ausencia, que la universidad no es la misma sin él; si bien tenemos sus escritos y recuerdos, el vacío es imposible de llenar. Hombres de su talla son pocos, pero nos queda el consuelo de su obra, la cual seguirá "gritando" en esta sociedad de sordos, donde, por fortuna, algunos afinan sus ojos y oídos, y descubren su descomunal y rica producción literaria. La esperanza en un futuro mejor con menos inequidad, desigualdad e injusticias como él soñaba contará con la inspiración y enseñanzas contenidas en su hermosa obra. 


\title{
Fernando Soto Aparicio, a man called Latin America*
}

Fernando Soto Aparicio (Socha, Boyacá, October 11, 1933-Bogotá, May 2, 2016)**

Soto Mancipe Carlos

Escobar López Maria Teresa

Pinzón Jorge

\begin{abstract}
This book is made with painful experiences of life itself ... More than a novel, it is a story. A painful story that repeats and will continue to be repeated as long as there is still in the world one homeless man, without freedom and without education; while walking under the sky a martyred being by his loneliness and his ignorance. (Soto Aparicio, 1956, p. 8)
\end{abstract}

I watched his chest that arrhythmic was moving, tired of so much struggle. I saw my mother who kept praying in silence, like all that weekend. I approached my wife for strength. I went back to my father and put my hand on his forehead, breathed slow and stopped, breathed again and finally stopped. My hands did not detach from his forehead, I closed his eyes, knew that his struggle was just over, he rested. My mother stood by the bed, prayed a little harder, kissed him, and with an overwhelming tranquility, with the greatest love in the world, dismissed him. It was eight forty in the morning on May 2, 2016.

After a year of struggle, with deep and terrible pains that impelled him to write his Log of the Agonizer, his old machine Olivetti is silent, no longer heard the clatter on paper when he worked with the word he wrote to more than 100 per minute with the fingers of the heart. There will be no more blank pages with their stories and as he always said: "when my voice is silent, my books will scream for me" and that work is just beginning.

In the article "a sea of silence in a world of words" my brother Jaime describes and remembers in a particular way:

I remember it was a complete disaster for manual labor. Small home fixes (something beyond changing a light bulb) became complicated tangles of cables, tools, bruises, and sufferings. My mother had to come to his aid and almost always ended up calling the plumber or the electrician or anyone, who in addition to doing the work had to "undo the wrongs" that my father had caused. If it were

With this title and part of the content, it is published as an introduction to the posthumous work of Master Soto Aparicio Ellas y yo (2017).

." This writing "A tres manos" counts on the participation of Carlos Soto, son of master Soto Aparicio -painter and graphic designer, dean of Graphic Design at Corporación Universitaria Unitec, Bogotá; María Teresa Escobar and Jorge Pinzón, all participants in the research 2356 "Narrative bioethics in the literature of Fernando Soto Aparicio. Moral issues and contributions to the resolution of conflicts and decision making". INV-HUM 2352. 
up to him, the cars should not have tires not to have to change them, and the only thing he did well was to put gas because of all other maintenance things were forgotten. Yes, my dad was denied for everyday things. But he was a superhero when it came to listening and giving advice.

He left us a great lesson where "love" is the axis of life, its thread, motive, and reason:

I think that love, like life, is a mirror that gives us back the face that we look at it. The love that is surrender, which is to give itself completely, also implies receiving the other in the same measure and is a both-way path that never ends and that, fortunately, is accompanying this road of life. The two parallels go road and path, always seeking that full moment that is perhaps, what justifies us, what gives us north, which becomes a compass to guide us in this sometimes difficult path of life. Love is, then, the companion par excellence, which never betrays and is what projects us beyond the term fixed for life.

All his work has a north, a constant concern to denounce, to show, to evidence the anxieties and questions of man on this continent:

The central axis of all my books is the man from Latin America, with his problematic, his daily anguish, his struggle to survive, his rebellion against injustice, his anger against the oppressors. The man who has to sell his labor power to the highest bidder; the one who does not have a house to live in; the one who, in this vast and alien world, did not have a furrow of his own. The one that learns to drink with the mother's breast milk, the rebellion against an unsustainable social situation and which, suddenly in the midst of all this daily barbarity, continues to seek peace. The one who can't afford a notebook for his children and who sees that the State has been closing schools and condemning the people to illiteracy. The one that looks terrified how that same state, that same government has been closing the hospitals, to the point where already the poor people do not have any social service in the field of health. The one who contemplates with amazement how the government he chose to take him along the right path of peace, harmony, coexistence, spends all the money from the national budget in gunpowder [...] we are burning the little money we have in war, and we do not pay a single cent for peace.

A man who kept his daily life to write and read, calm and serene. Among the many memories, my brother Jaime finishes his reflection and notes about my father:

I had, with my brothers, the happiness and blessing of having and enjoying my dad for 60 years, many years longer than most people in this country have their parents alive. Today, with my four flesh-and-blood brothers and my 72 brothers in paper and ink, we feel the loneliness and his absence. Life gave us the opportunity to give him back a little bit of everything he gave us. By caring for him during his illness, the papers were reversed, and he became our son. That's how we felt him: fragile, defenseless, scared, sad, in pain, hopeless ... There we were all: his five children under the organized, diligent, loving and devoted baton of my mother and unconditionally supported by my sister-in-law Maria Consuelo, her brother Eduardo and his brother-in-law Alfonso, dedicated to making his last days less painful, to pamper him, to comfort him, to hide him from death for a few 
more days. He arranged for us to put many books in his room, stacks of books that accompanied him in his wild dreams and his sleeplessness. He also wanted the light on permanently, we thought it was because he was afraid that the grim reaper would take advantage of the darkness, but I believe that it was to see his books keeping him company, guarding, protecting and sheltering him, ready to surrender to Charon. To pay for their journey beyond the Stygian lagoon, traversing the Acheron towards eternity and glory.

That is why, along with his monumental work, read by thousands, his love verses, his words denouncing injustices, his faith in love, the fight raged for a year against his illness, knowing that he had already won the race to the death of oblivion through his books that will scream for him forever, the image that we keep as a writer and as a man will last forever with millions of readers who will continue to travel through his pages to do his work a wonderful legacy to the Castilian letters in this part of America for the World.

\section{Carlos Soto}

Master, you're still here.

A year after your departure, your leisurely walk, sweet smile, intelligence, favorable comments; sometimes scathing, most kind, are still here. Your presence is felt in the Faculty of Education and Humanities. You are in the pleasant memory of your wisdom, your amiable gestures, in the evocation of your infinite and intelligent patience in the face of clumsiness and mediocrity, in the opportune quotation that is often heard of your illustrated phrases and celebrations pronounced by professors, in the meetings of the reading club that bears your name and that you founded and impulse until the last moment, in the investigations that we make of your works of deep historical, political, bioethical ${ }^{1}$ content, in the study of your books and poems in the interior of Literacy classes. Really, you're still here.

It may happen that it is not necessary to have to personal interaction with a writer to be able to know him in his deepest dimension that of his own action, there in day-to-day life, in the nakedness of daily living, in the simple world of fine print.

It happened to me with Cortazar, later with Serrat and almost at the same time with Blades. Just reading and listening to them, I knew them to be deeply human.

With the master, Fernando Soto Aparicio has not been different. I could never look closely at his eyes; neither experience the sensation of being at the head of a great human being. I only knew that I missed the delight of his direct conversation and that his prose and these recent poems of always, testified to his personal greatness

1 In this regard, in 2017 we have been carrying out the bioethical narrative research in the literature of Fernando Soto Aparicio. Moral issues and contributions to the resolution of conflict and decision making. INVHUM 2352 Lead investigator; María Teresa Escobar López, co-investigator; Luis Flores Portero. Professor and researcher at the Military University Nueva Granada. 
From our jobs are no longer observed his permanent cubicle companions: his books and his cats. Who did not know about his devotion to reading and the eagerness with which he expected people to read and understand what makes us better people? Frequent visitors came to the office wanting to hug him, congratulate him on his literary work, receive advice to write, light, a tip, some illustration of how to performed the poetic and literary work; others raided his desk to make a film record or take a picture. Almost always we saw them leave not only with the pleasant memory of being attended with the simplicity that only owns who is wise, also they used to carry under the arm a copy of his books, always given away with absolute detachment and complacency, adducing its celebrated arguments "a book must go, there is nothing sadder than a book kept or displayed in a shop window" or, "a book does not have a hundred sheets, a book has a hundred wings, a book takes us to unknown worlds, peek us through wonderful windows, makes fly our imagination, moves our feelings and sensations that otherwise could not".

$\&$

Long ago, I used to go to an old café in the center of the city, sitting there in a red chair as old as the table and like the coffee itself, I used to drink a delicious black coffee that came out through the arteries of an immense German machine brought in 1938 and manipulated only by Mrs. Ines, the administrator of the place.

On one occasion, sitting at the far end of the room was the master Soto Aparicio, tasting the red wine and reading-writing what was perhaps the correction of one of his many works.

The people greeted him very respectfully, and some asked him about his things, his writings. He would greet them and respond to them broadly, as if he wanted to retain every moment of conversation, every piece of the other's existence, being generous with the word.

I wanted to go up to greet him, as the others did, but I did not do it, I did not know what to say. Just look at him at a discret distance.

In the background one could hear, at a moderate volume, the bambuco four questions interpreted by Obdulio and Julian.

$\&$

The collection of cats that adorned the office was a testimony of love and admiration for them and at the same time, a demonstration of the love expressed by those who knew him and knew that this made more pleasant his stay in the office. They witnessed the exception of the time when we had the privilege of having his presence in this house of studies for more than seventeen years. 
In an interview conducted by Hernán Orjuela for television, about the publication of Camino que anda, the Master, in his unequaled style, tells how this text tells the recent history of Latin America, describing the rigor it represents the research that precedes not only this one but each one of his works, more than seventy books, behind which there is a conscientious and strict study. The secret notebooks, in which he recorded all the work that preceded his books, are the real testimony of the social and committed writer who gives an account of the history of our time, whose daily work we were fortunate to accompany in recent years, his desire to register and go to friends and close relatives to trace, for example, the indigenous cultures of the South of the continent to have more information than they already had and write La sed del agua How not to remember and to miss also the beautiful writings that he gave us on Woman's Day, Mother's Day or the greetings in New year's Eve; always full of poetry and wisdom.

$\&$

I discovered his poetry a long time after learning of some of his novels, novels that "put me" to read in school and other few that I read for personal taste when questions about society and life of people began to prowl the head and feel. Then I was certain of the concern of the Master Soto Aparicio for the unnamed, the unfortunate, the excluded, the people for whom I asked myself and I was revealed his permanent denunciation of what happened in his narrations that seemed to me real denunciations.

The Master must have been part of that select group of well-known Latin American writers who told what was happening on the continent in the harsh times of dictatorships and rebellions. But he did not have the same recognition. (Jorge Pinzón)

$\&$

So hard (those "times of dictatorships and rebellions") as reflected in the lives of countless characters. In his first novel, The Blessed, the characters are punished without apparent reason or guilt, as is the case of Mario, who is paying a high price to unleash his love impulses to Tona: "The young man fell to the floor, bathed in blood. It was part of his punishment" (55). ${ }^{2}$ In a way, the characters experience that same lack of recognition or understanding by a markedly hostile environment, all of which causes the author to call them, not without the necessary irony, "blessed". (Luis Flores Portero)

How not to remember the poetry of Fernando Soto Aparicio? This one, with which we were privileged to our enjoy hours of work, occupies a place of honor in Colombian and Latin American poetry; reveals not only his literary and artistic wealth but his values, his feelings, his wisdom. The Master succeeded and would continue to do it with his fruitful work as he

2 Soto Aparicio, F. (2010). Los bienaventurados. Bogotá: Universidad Militar Nueva Granada. 
constantly repeated, to be the expression of a silent society: "The writer has an obligation to speak for them, for those who are silent, for those who have no voice, for whom are afraid. "His eagerness to educate through literature was evident; his mottos about reading were his daily work and living, wise, as anyone who read and appreciated the arts would distance himself from ignorance and violence. He was a preacher of peace and love like no other. ${ }^{3}$

Fernando Soto Aparicio was and will continue to be the political and human writer who knew, as few, how to portray the history of his time, always critical of corruption, violence and any form of injustice; faithful to its principles and values, managed to personify the true essence of an ethical life. The Master Soto, undoubtedly, belongs to the category of full letter humanist. He possessed the generosity that was so elusive to his comrades in the arts and so absent in the State.

Literature is a draconian discipline, terrible, but wonderful. There are very valuable people, I will not say names because I would let some out, but there are people who have collected the flags that maybe we are going to leave. There are people who will replace us with luxury, who are winning us, who have accepted the international challenge of literature. I am very pleased for that; every new author is as if I had discovered, is a great joy. ${ }^{4}$

$\&$

I discovered his poetry quite sometime later when I wanted to listen to several friends who knew of his poetic virtues; I found the letters of love and exaltation of the woman and I knew that it was true:

Mature and ductile body for enjoyment.

Body of dune, palm wind,

Illuminated bay.

(From the poem Mature and ductile body).

Or from the poem Pecado (Sin):

Your skin no longer knows me to sin

That maybe he might know me one day.

Your eyes watch me tired

Because their fantasy died.

3 Suffice it to recall that he anticipated proclaiming the chair of peace and the need to teach and cultivate love. In texts such as Recomendación para todos los días en Cartilla para mejorar el mundo: "There should be a chair to be called, perhaps", Pedagogy of Peace"; where you will teach to plant a tree, build a board, write an idea. And another class that was not just sexual education, but "Preparation for Love". Perhaps this way we would straighten out the twisted world-walk, to make it really better. "Journal Investigación y Desarrollo Social 1999.

4 Interview with Juan Villamil. "I've always been in a fight with God”: Fernando Soto Aparicio 24 Apr 2012. 
Or simply of life and its outcome in the poem Olvido (Forgotten);

Hey when I'm gone

You will feel me as close as now.

In the song of a bird in the dawn,

In the mist that rises among the roses,

In the deep mirrors of the cistern

Where the timid clouds drown.

In the singing of a child on the street,

In the pungent taste of defeat,

Dancing in the joy of sowing

With arms open at dawn

So that in them the wind stops

And make your new nest the doves.

$\&$

Very few in the interior of the country do justice to their extensive and valuable work. Surprising to hear as writers who belong to the society of mutual praise, they ponder each other without even mentioning the Master Soto, who is one of the greatest. To the State for which he worked for more than twenty years in the court of Santa Rosa de Viterbo and in the Consulate of France and from which he received nothing in return, not even the rights which he had by an old-age pension. In the aforementioned interview with Hernán Orjuela, this journalist said that it was incredible that in Colombia he had not received any awards from the government while on behalf of national institutions, other countries and continents, the titles and decorations represent a long list.

The master Soto happened to him as one of the historical personages of his books, "Pedro Pascasio, hero before 12 years", to whom the promised reward never arrived. Justice, to Pedro Pascasio, is made the text of the master, showing his integrity and rectitude. He records in that book how the history of independence could have followed another course if it were not for this intrepid and forgotten teenager.

The truth is that Fernando Soto Aparicio, was a writer who had to forge a name against the tide, as usually happens with who is priceless, nor does it match power or money. On the contrary, like Don Quixote, he deals with injustice and the needy. The same master Soto referred how, after touching many doors of universities, publishers, etc. in our country, was in Spain, participating in a contest, where he managed to publish his first book: The Blessed. Indeed, his role in the world obeyed somewhat to what Gonzalo Arango said in 1966:

This Fernando Aparicio, so serene, so quiet, so absent in his presence, gave me the impression of being like those street posts that are not seen, that are not noticed because they are always there, 
net and necessary, and that to discover them have to stumble upon them, and even to blow their noses against the strength of their resistance. I saw it and felt it like a power pole whose existence a dog discovers when it pees, but so present despite the uninterested looks. So necessary and justified in his condition of 'post' because he knows that his mission is to be there to transmit the light, to communicate to men

\section{$\&$}

Today, for very wonderful reasons, I find myself closer to the master Soto Aparicio, paradoxically after his departure. Today I am sure that I would approach my table and not know exactly what to ask him, perhaps I would try to talk about the music, the corridor, and his atavistic guilty ancestor..., but beautiful.

\section{$\&$}

It is certain that the time and the undoubted importance of your work will immortalize you in Colombian, Latin American and world history. For now, it is enough only to say that, your absence is felt more and more, that the university is not the same without you, although we have your writings and memories; the void is impossible to fill, men of your size are few, we have the comfort of your work which will continue to "scream" in this society of deaf, where, fortunately, some refine their eyes and ears discovering your enormous and rich literary production. Hope for a better future with less inequity, inequality, and injustices as you dreamed, will have the inspiration and teachings contained in your beautiful work, master. 


\title{
Fernando Soto Aparicio, um homem chamado América Latina*
}

Fernando Soto Aparicio (Socha, Boyacá, 11 de outubro de 1933-Bogotá, 2 de maio de 2016)"

Carlos Soto Mancipe

María Teresa Escobar López

Jorge Pinzón

\begin{abstract}
Este livro é feito com experiências dolorosas da própria vida [...] Mais do que uma novela, é uma história. Uma dolorosa história se repetindo e que continuara a se repetir enquanto haja no mundo um só homem sem-teto, sem liberdade e sem educação; em quanto caminhe sob o céu um ser atormentado por sua solidão e por sua ignorância (Soto Aparicio, 1956, p. 8)
\end{abstract}

Olhei para seu peito que arrítmico se movia cansado de tanta luta. Eu vi a minha mãe que em silencio continuava orando, como tudo esse fim de semana. Aproximei-me para minha esposa para ter fortaleza. Voltei para o meu pai e coloquei minha mão em sua testa, respirou lenta e parou, respirou novamente e finalmente parou. Não tire minhas mãos da sua testa, fechei seus olhos, eu sabia que sua luta apenas terminava, ele descansou. Minha mãe parou-se ao lado da cama, rezou um pouco mais forte, beijou-o e com esmagadora tranquilidade, com o maior amor do mundo, o despediu. Eram as 08:40 a. m. do dia 2 de Maio de 2016.

Depois de um ano de luta, com dores profundos e terríveis que o levaram a escrever o seu Diário de bordo do agonizante, a sua velha máquina Olivetti guardou silêncio, não se escutava mais o tamborilar sobre o papel ao trabalhar com a palavra que escrevia a mais de 100 por minuto com os dedos do coração. Não serão preenchidas mais páginas em branco com suas histórias e como sempre disse: "Quando minha voz fique calada, meus livros vão gritar por mim"; esse trabalho está apenas começando.

No artigo "Um mar de silêncios em um mundo de palavras" meu irmão Jaime descreve-lo e lembra de modo particular:

Lembro-me que foi um desastre completo para os trabalhos manuais. Os arranjos domésticos pequenos (aquilo que fosse além de substituir uma lâmpada) voltavam-se um complexo emaranhado de cabos, ferramentas, hematomas e sofrimentos. Minha mãe tinha que vir em seu auxílio e quase

Com este título, e parte do conteúdo, se publica como introdução na obra póstuma do mestre Soto Aparicio Elas e eu. Este escrito feito a "três mãos", com a participação de Carlos Soto, filho de Mestre Soto Aparicio -pintor e designer gráfico, Decano de Design Gráfico na Corporação Universitaria, Unitec, Bogotá-; María Teresa Escobar e Jorge Pinzón, todos participantes da pesquisa 2356 Bioética narrativa na literatura de Fernando Soto Aparicio. problemática moral e contribuições para a resolução de conflitos e tomada de decisões. INV-HUM 2352. 
sempre acabou chamando o encanador ou eletricista ou ao quem fosse, quem além de realizar o trabalho tinha que "desfazer os erros" que meu pai tinha causado. Se por ele fosse, os carros não deveriam ter rodas para evitar ter que mudá-las, e o único que fazia bem era pôr combustível, pois de todas as outras coisas de manutenção esquecia. Sim, meu pai foi negado para coisas cotidianas. Mas ele era um super-herói na hora de ouvir e dar conselhos.

Deixo-nos uma grande lição que diz que o amor é o eixo da vida, sua linha condutora, o motivo e a razão:

Eu acho que o amor, como a vida, é um espelho e que nos retorna o rosto com que olhamos para ele; e que o amor que é entrega, que é dar-se por completo, também envolve receber ao outro com a mesma intensidade e é um rasto de via dupla que nunca termina e que sempre, felizmente, vai acompanhando este caminho da vida, eles vão os dois paralelo; trilhas e caminhos, procurando sempre esse momento plenificante que é o que talvez nos justifica, dando-nos um norte, o que se torna numa bússola para nos guiar neste caminho por vezes difícil da vida. O amor é, portanto, o parceiro por excelência, que nunca trai e é o que nos impulsiona para além do prazo fixado para a vida.

Toda a sua obra tem um norte, uma preocupação constante para denunciar, mostrar e evidenciar as ansiedades e as perguntas do homem deste Continente:

O eixo central de todos os meus livros é o homem na América Latina, com seus problemas, com sua angústia diária, com sua luta pela sobrevivência, com sua rebelião contra a injustiça, a sua ira contra os opressores; ele é o homem que deve vender sua força de trabalho para o maior lance; aquele que não tem uma casa onde viver; aquele que, neste mundo largo e alheio, não teve o seu próprio sulco; aquele que aprende a beber com o leite materno a rebeldia contra uma situação social insustentável; aquele que de repente, no meio de toda essa barbárie cotidiana, continua a buscar a paz; aquele que não tem para comprar um caderno para seus filhos; aquele que vê que o Estado tem fechado escolas e condenando as pessoas para o analfabetismo; aquele que olha aterrorizado como esse mesmo Estado, esse mesmo governo tem ido fechando hospitais, ate o ponto que já as pessoas pobres não tem nenhum serviço social no campo da saúde; aquele que contempla com assombro como o Governo que ele escolheu para levá-lo no caminho certo de paz, da harmonia, da convivência, gasta todo o dinheiro do orçamento nacional em pólvora [...] estamos queimando o pouco dinheiro que temos na guerra e não gastamos nenhum centavo para a paz.

Um homem que mantinha sua rotina diária para a escrita e a leitura, calmo e sereno. Entre as muitas lembranças, meu irmão Jaime termina a sua reflexão e anota sobre meu pai:

Tive, com meus irmãos, a felicidade e a bênção de ter e desfrutar a meu pai durante 60 anos, muito mais anos do que a maioria das pessoas neste país tem a seus pais vivos. Hoje, com os meus quatro irmãos de carne e osso e com meus 72 irmãos de papel e tinta sentimos a solidão e sua ausência. A vida deu-nos a oportunidade de dar de volta para ele uma pequena parte de todo o que ele nos deu. Ao cuidar dele durante a sua doença, os papéis foram invertidos, e ele tornou-se como nosso filho. Assim o sentimos: frágil, indefeso, assustado, triste, dolorido, sem esperança... Ali estávamos todos: 
seus cinco filhos sob a batuta organizada, diligente, amorosa e devota da minha mãe e apoiados incondicionalmente por minha cunhada María Consuelo, seu irmão Eduardo e seu cunhado Alfonso, dedicados a tornar menos penosos seus últimos dias, a consenti-lo, a mimá-lo, a confortá-lo, a escondê-lo por alguns dias mais à morte. Ele ordenou que em seu quarto nos puséssemos muitos livros, eram pilhas de livros foram acompanhando-o em seus sonhos tempestuosos e em seus estados de vigia. Também queria que a luz estivesse permanentemente acesa, nós pensamos que isso, era porque ele estava com medo que o ceifeiro aproveitara traiçoeiramente a escuridão, mas acredito que foi para ver os seus livros fazendo-lhe companhia, montando guarda, protegendo-o e abrigando-o, prontos para entregar-se a Caronte para pagar sua viagem além da Lagoa Estige, sulcando o Aqueronte para a eternidade e a glória.

Portanto, junto a sua obra monumental, lido por milhares de pessoas, seus versos que namoram, suas palavras denunciando as injustiças, a sua fé no amor, a luta sustentada em forma raivosa por um ano contra a sua doença, sabendo que ele já tinha lhe ganhado a corrida para a morte do esquecimento através de seus livros que vão gritar por ele para sempre, a imagem que guardamos como escritor e como homem vai durar para sempre junto a milhões de leitores que vão continuar a visitar suas páginas para fazer do seu trabalho um legado maravilhoso para as letras em espanhol nesta parte da América para o mundo.

Carlos Soto

\section{Mestre, o senhor segue aqui.}

Um ano depois de sua partida, o seu caminhar pausado, seu sorriso doce, seus comentários inteligentes, oportunos, às vezes mordazes, a maioria amáveis ainda estão aqui. Sua presença é sentida na Faculdade de Educação e Humanidades. Esta nas boas memórias de sua sabedoria, seus gestos amáveis, evocando a sua infinita paciência e inteligente contra a incompetência e a mediocridade, na citação oportuna que é escutada freqüentemente de suas frases ilustradas e exaltantes proferidas por algum professor; nas reuniões do clube de leitura que leva seu nome e que você fundou e impulsou até o último momento, nas pesquisas que fazemos de suas obras de profundo conteúdo histórico, político, bioético ${ }^{1}$, no estudo de seus livros e poemas dentro das aulas de leito-escritura; realmente, você ainda está aqui.

Pode acontecer que tudo ocorra para que não seja necessário ter de interagir pessoalmente com um escritor para puder conhecê-lo em sua dimensão mais profunda, que é a de seu agir pessoal, ai no dia -a-dia, no quotidiano que fica nua no mundo simples da letra miúda.

1 Ao respeito, em 2017 temos vindo a realizar a investigação Bioética narrativa na literatura de Fernando Soto Aparicio. Problemática moral e contribuições para a resolução de conflitos e tomada de decisões. INV-HUM 2352 Investigadora principal: Maria Teresa Escobar Lopez; Co-investigador: Luis Flores Goleiro, docente pesquisador da Universidade Militar Nueva Granada. 
Aconteceu para mim com Cortazar, depois com Serrat e quase simultaneamente com Blades. Somente lendo-os e ouvindo-os, eu sabia-lhes profundamente humanos.

Com o Mestre Fernando Soto Aparicio não tem sido diferente. Nunca consegui olhar de perto seus olhos, nem experimentar a sensação de estar à frente de um grande ser humano. Eu só sabia que estava faltando o prazer de sua conversa direta e que suas prosas e estes poemas recentes de sempre davam testemunho de sua grandeza pessoal. (Jorge Pinzón)

Desde os nossos lugares de trabalho já não são vistos seus permanentes companheiros de cubículo: seus livros e seus gatos. ¿Quem não sabia de sua devoção à leitura e a avidez com que esperava que as pessoas de lesem e entendessem que isso nos torna pessoas melhores? Visitantes frequentes vinham para o escritório querendo abraçá-lo, para felicitá-lo por sua obra literária, receber uma ideia para a escrita, uma luz, uma dica, alguma ilustração de como você executou sua obra poética e literária; outros invadiram sua mesa para fazer um registro fílmico ou tirar uma foto. Quase sempre os vimos sair, não só com boas lembranças de ter sido tratados com sua da simplicidade que só tem um que é sábio, mas também levavam debaixo do braço uma cópia de seus livros sempre dados de graça, com desprendimento absoluto e complacência, citando seus famosos argumentos: "um livro deve ir, não há nada mais triste do que um livro guardado ou exibidos em uma vitrine" ou "um livro não tem uma centena de páginas, um livro tem cem asas, um livro nos leva a mundos desconhecidos, nos assoma por janelas maravilhosas, faz-nos voar a imaginação, nos move sentimentos e sensações que de outra forma não se poderia".

\section{$\&$}

Há muito tempo, eu freqüentava um velho café localizado no centro da cidade, lá sentado em uma cadeira vermelha velha como a mesa e como o próprio café, costumava tomar um café preto delicioso usado que saia através das artérias de uma enorme máquina alemão que trouxeram em 1938 e manipulada exclusivamente pela Sra. Inês, a administradora do site.

Em alguma ocasião, sentado no fundo da sala estava o mestre Soto Aparicio, tomando o cafezinho preto e lendo-escrevendo o que talvez fosse a correção de uma das suas numerosas obras.

As pessoas cumprimentavam-o respeitosamente e alguns perguntavam lhe sobre suas coisas, seus escritos. Ele cumprimentou-os e respondera-lhes amplamente, como se manter cada momento da conversa, cada pedaço de existência do outro, sendo generoso com a palavra.

Então eu quis chegar perto para cumprimentá-lo, como os outros fizeram, mas não o fiz, eu não sabia o que dizer-lhe. Basta olha-lo numa distância prudente. 
No fundo podia se ouvir, a um volume moderado, o bambuco Quatro perguntas interpretado por Obdulio e Julian.

\section{$\&$}

A coleção de gatos que adornavam o escritório constituíam testemunho de amor e admiração por eles e ao mesmo tempo mostrar o amor expresso por quem o conheciam e sabia que isto fazia mais fácil sua estada no escritório. Eles foram testemunhas de exceção do tempo que tivemos o privilégio de ter a sua presença nesta universidade por mais de 17 anos.

Em uma entrevista realizada por Hernán Orjuela para a televisão, respeito da publicação de Caminho que anda, o mestre, no seu estilo inigualável, conta como esse texto percebe a história recente da América Latina, contando o rigor que representa a pesquisa que precede não só a esta, mas também a cada uma de suas obras, mais de setenta livros, atrás da qual há um estudo consciencioso e rigoroso. Os cadernos secretos, nos que registraram todo o trabalho que precedeu seus livros, são o verdadeiro testemunho do escritor social e comprometido que da conta da história do nosso tempo, trabalho cujo cotidiano tivemos a sorte de acompanhar nos últimos anos, a sua ânsia de registrar e vir para os amigos e familiares para rastrear por exemplo as culturas indígenas do sul do continente para ter mais informação do que já possuía e escrever $A$ sede da água. Como não lembrar e sentir falto também dos belos escritos que nos fizera chegar o dia da mulher, o dia da mãe ou o cumprimento do ano novo; sempre cheio de poesia e sabedoria.

\section{$\&$}

Descobri sua poesia bastante tempo após de alguns de saber de algumas de suas novelas, novelas que "puseram-me" a ler na escola e outras poucas que li por prazer próprio quando as perguntas sobre a sociedade e a vida das pessoas começaram a me dar volta na cabeça e o sentir. Então eu tive certeza da preocupação do mestre Soto Aparicio para os sem nome, os miseráveis, os excluídos, as pessoas para quem eu me perguntava e foi-me revelada sua denúncia permanente do que acontecia em suas narrações que me pareciam denúncias reais.

O mestre deveu ter sido parte desse grupo seleto de escritores latino-americanos amplamente reconhecidos que narravam o que estava acontecendo no continente nos tempos difíceis das ditaduras e rebeliões. Mas ele não teve baita reconhecimento. (Jorge Pinzón)

\section{$\&$}

Tão difíceis (esses "tempos das ditaduras e as rebeliões") como se reflete nas vidas de seus incontáveis personagens. Em sua primeira novela, Os Bem-aventurados, os personagens são punidos sem 
aparente razão ou culpa, como é o caso de Mario, quem aos poucos está pagando um preço alto por ter dado rédea livre a seus impulsos amorosos em direção a Tona: "O jovem caiu no chão, coberto de sangue. Era parte de sua punição (p. 55). ${ }^{2}$ De certa forma, os personagens experimentam essa mesma falta de reconhecimento ou compreensão por um ambiente marcadamente hostil, tudo o qual faz com que o autor os chame, não sem a necessária ironia, "Bem-aventurados" (Luis Flores Portero)

¿Como podemos esquecer a poesia de Fernando Soto Aparicio? Esta, com a qual privilegiadamente mantinha-nos contentes as horas de trabalho, ocupa um lugar de honra na poesia colombiana latino-americana; revela não só a sua riqueza literária e artística, mas também os seus valores, seu sentir, sua vasta sabedoria. O Mestre conseguia, e vai continuar fazendo-o com sua frutífera obra como constantemente repetida, ser a expressão de uma sociedade muda: "o escritor é obrigado a falar por eles, pelos que calam, por aqueles que não têm voz, pelos que têm medo". Sua ânsia de educar através da literatura era evidente, seus lemas referente à leitura eram seu diário quefazer e viver; sabia como ninguém que quem lera e apreciara as artes afastar-se-ia da ignorância e da violência. Foi pregador da paz e do amor como nenhum outro. ${ }^{3}$

Fernando Soto Aparicio foi e continua sendo o escritor social e humano que soube transpor como poucos a história de seu tempo, sempre crítico da corrupção, a violência e de todas as formas de injustiça; fiel aos seus princípios e valores, conseguia personificar a verdadeira essência de uma vida ética. O mestre Soto Aparicio pertence, sem dúvida nenhuma, para a categoria de humanista plenamente. Ele teve a generosidade que era tão esquiva para os seus colegas nas artes e tão ausente no Estado.

\begin{abstract}
A literatura é uma disciplina draconiana, terrível, mas maravilhosa. Há pessoas muito valiosas, eu não vou dizer nomes porque iriam sê-me escapar alguns, mas há pessoas que tem coletado as bandeiras que talvez nós vamos deixar. Há pessoas que nos substituíram com luxo, que está-nos ganhando, que aceitou o desafio internacional da literatura. Eu estou muito satisfeito por isso, cada novo autor é como se eu tivesse descoberto, é uma grande alegría. ${ }^{4}$
\end{abstract}

$\&$

Eu descobri sua poesia muito tempo após, quando querendo ouvir vários amigos que sabiam de suas virtudes poéticas encontrei-me com as letras do amor e a exaltação da mulher, e soube que era verdade:

2 Soto Aparicio, Fernando. (2010). Os bem-aventurados. Bogotá: Universidade Militar Nueva Granada, p. 55.

3 Basta lembrar que se antecipou para proclamar a cátedra da paz e a necessidade de ensinar e cultivar o amor. Em textos como Recomendação para cada dia em Cartilla para melhorar o mundo: "Deveria existir uma cátedra que se chame talvez, "Pedagogia da paz", onde é ensinado para plantar uma árvore, para construir um painel, para escrever uma ideia. E outra classe que não seja apenas Educação sexual, mas "Preparação para o Amor." Talvez assim endereçaríamos o tão torcido caminho do mundo, para que seja realmente muito melhor. " Revista Investigación y Desarrollo Social 1999.

4 Entrevista com Juan Villamil. "Eu sempre tenho brigado com Deus": Fernando Soto Aparicio 24 de abril de 2012. 
Corpo maduro e dúctil para o gozo.

Corpo de duna, vento de palmeira, oquidão de baía iluminada.

(do poema Corpo maduro e dúctil)

Oo do poema Pecado:

Tua pele já não me sabe aos pecados

A que talvez ele pôde saber-me um dia.

Teus olhos contemplam-me fatigados

porque morreu-se lhes a fantasia.

Ou simplesmente da vida e seu desenlace no poema Esqueço

Ein: quando eu for embora da vida

Sentir-me-ás tão perto como agora.

No canto de um pássaro na alvorada,

na bruma que surja entre as rosas,

nos profundos espelhos do poço

onde as nuvens tímidas se afogam.

No canto de um menino pela rua,

no acre sabor da derrota,

dançando na alegria da semeia

com os braços abertos à aurora

para que em eles detenha-se o vento

e façam seu novo ninho as pombas.

$\varepsilon$

Muito poucos dentro do país fazem justiça ao seu trabalho extenso e valioso. Surpreende ouvir como escritores que pertencem à sociedade do mútuo louvor ponderam-se entre eles sem sequer mencionar o mestre Soto Aparicio, que claramente é um dos grandes nomes. Ao próprio Estado para o qual ele trabalhou mais de vinte anos na corte de Santa Rosa de Viterbo e no Consulado da França, e que recebeu nada em troca, nem mesmo os direitos que por lei tinha de uma pensão de velhice. Na entrevista acima mencionada com Hernán Orjuela, este jornalista significava que era incrível que na Colômbia não tinha recebido qualquer prémio pelo Governo, enquanto que em nome de instituições nacionais em outros países e continentes, os títulos e condecorações representam uma longa lista.

Ao Mestre Soto Aparicio aconteceu-lhe igual que a um dos personagens históricos de seus livros, "Pedro Pascasio, herói antes dos 12 anos", a quem a recompensa prometida nunca chegoulhe. A justiça, a Pedro Pascasio, se a faz o texto do mestre, mostrando a sua integridade e retidão. 
Ele registrou no livro como a história da independência poderia ter seguido outro rumo se não fosse por este adolescente ousado e esquecido.

A verdade é que Fernando Soto Aparicio foi um escritor ao que lhe tocou forjar um nome contra a maré, como muitas vezes acontece com aqueles que não têm preço, nem faz o jogo ao poder ou ao dinheiro. Pelo contrário, como Dom Quixote, ele teve o cuidado da injustiça e os necessitados. Ele mesmo referia-se como, depois de tocar muitas portas de universidades, editoras, etc. em nosso país, foi em Espanha, participando de um concurso, onde ele conseguiu publicar seu primeiro livro: Os bem-aventurados. Na verdade, o seu papel no mundo cumpria com o dito por Gonzalo Arango em 1966:

\footnotetext{
Este Fernando Aparicio, tão sereno, tão calmo, tão ausente em sua presença, me deu a impressão de ser como os postes de rua que não são vistas, que não são notados, porque eles estão sempre lá, exatos e necessários, e que para descobrir-lês tem que tropeçar com eles, e até mesmo estourar seus narizes contra a força de sua resistência. Assim eu o vi e o senti como um poste de serviço público de eletricidade cuja existência revela-nos um cão quando ele faz xixi, mas tão presente, apesar dos olhares que passam indiferentes. Tao necessário e justificado em sua condição de 'poste' porque ele sabe que sua missão é estar ali para transmitir a luz, para comunicar aos homens.
}

\section{$\&$}

Hoje em dia, por razões muito bonitas, eu me encontro mais perto do mestre Soto Aparicio, paradoxalmente depois de sua partida. Hoje tenho certeza de que me aproximaria para sua mesa e, sem saber exatamente o que perguntar, talvez tentasse falar sobre as músicas, do salão e seu atávico antepassado culpável, mas belo.

\section{$\&$}

Certamente o tempo e a importância indubitável de seu trabalho vão imortaliza-lo na história colombiana, da América Latina e do mundo. Por agora é suficiente dizer que cada vez mais se sente a sua ausência, que a universidade não é a mesma sem ele; embora tenhamos seus escritos e memórias, o vácuo é impossível de preencher. Homens da sua dimensão são poucos, mas temos o consolo de sua obra, a qual vai seguir "gritando" nesta sociedade de surdos, onde, felizmente, alguns aguçam seus olhos e ouvidos, e descobrem sua enorme e rica produção literária. A esperança de um futuro melhor com menos iniquidade, desigualdade e injustiça como ele tinha sonhado vai contar com a inspiração e ensinos em sua bela obra. 